The Free Internet Journal

for Organic Chemistry
Paper

Arkivoc 2018, part v, 0-0

to be inserted by editorial office

\title{
Rearrangement of a 5,7-di-tert-butyl-2-(quinolin-2-yl)-1,3-tropolone into a pentalene derivative
}

Yurii A. Sayapin, ${ }^{a}$ Alexandra A. Kolodina, ${ }^{b}$ Duong Nghia Bang, ${ }^{c, d}$ Evgeny A. Gusakov, ${ }^{b}$ Igor V. Dorogan, ${ }^{b *}$ Vitaly N. Komissarov, ${ }^{b}$ Gennadii S. Borodkin, ${ }^{b}$ Valery V. Tkachev, ${ }^{e}$ Duong Ngoc Toan, ${ }^{d}$ Vu Dinh Hoang, ${ }^{f}$ Tran Dai Lam, ${ }^{\mathrm{g}}$ Gennadii V. Shilov, ${ }^{\mathrm{e}}$ Serguei M. Aldoshin, ${ }^{\mathrm{e}}$ and Vladimir I. Minkin ${ }^{\mathrm{a}, \mathrm{b}}$

a Southern Scientific Center of Russian Academy of Science, 41 Chekhova Str.,Rostov on Don 344 006, Russia

${ }^{b}$ Institute of Physical and Organic Chemistry, SFedU, 194/2, Stachka Av., Rostov on Don 344 090, Russia

'Thai Nguyen University of Sciences, Tan Thinh Ward, Thai Nguyen, Vietnam

${ }^{d}$ Thai Nguyen Institute of Science and Technology, Tan Thinh Ward, Thai Nguyen, Vietnam

${ }^{e}$ Institute of Problems of Chemical Physics, Russian Academy of Sciences, 1 Acad. Semenov Av. 142 432, Chernogolovka, Russia

${ }^{f}$ Hanoi University of Science and Technology, 01 Dai Co Viet, Hai Ba Trung, Hanoi, Vietnam

${ }^{g}$ Graduate University of Science and Technology, Vietnam Academy of Science and Technology,

18 Hoang Quoc Viet, Cau Giay, Ha Noi, Vietnam

Email: id@ipoc.sfedu.ru, sayapin@ipoc.sfedu.ru

Received 01-25-2018

Accepted 04-14-2018

Published on line $06-17-2018$

\section{Abstract}

Acid-catalyzed rearrangement of 5,7-di-tert-butyl-2-(4-chloro-6,8-dimethylquinolin-2-yl)-1,3-tropolone leads to $(R, S)$-5-tert-butyl-2-(4-chloro-6,8-dimethyl-1H-quinolin-2-ylidene)-3,3,3a-trimethyl-3,3a-dihydropentalene$1,6(2 \mathrm{H}, 6 \mathrm{aH})$-dione. The structure of the rearrangement product is established by 2D-correlation NMR and $\mathrm{X}$-ray diffraction. The relative thermodynamic stability and tautomeric isomers of the new compound were evaluated by means of quantum chemical methods. A reaction mechanism is suggested.

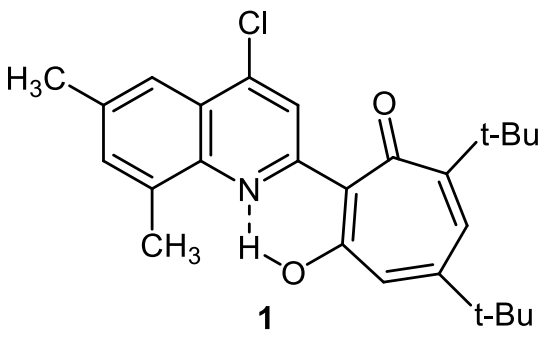<smiles>Cc1cc(C)c2c(c1)C(Cl)=CC(=C1C(=O)C3C(=O)C(C(C)(C)C)=CC3(C)C1(C)C)N2C=O</smiles>

Keywords: 1,3-Tropolone, Wagner-Meerwein rearrangement, hydrogen bonds, X-ray diffraction 


\section{Introduction}

The high biological activity of troponoids is related to the presence of a pharmacophore center, which is based on the seven-membered carbocyclic system. At the same time, the variety of pharmacological properties is determined by the nature and position of functional groups in the tropolone ring. ${ }^{1}$ That is why the development of methods for the functionalization of the seven-membered ring of 2-heteroaryl substituted 1,3-tropolones is a priority task. A promising method for the synthesis of 1,3-tropolone derivatives is based on the reaction of 2-methyl-containing heterocycles with substituted 1,2-benzoquinones leading to 2-(quinolin-2yl)-, ${ }^{2,3}$ 2-(quinoxalin-2-yl)-, ${ }^{4}$ 2-(benzazol-2-yl)-, ${ }^{5}$ and other 1,3 -tropolones. ${ }^{6-8}$

In the present work, we report an unusual acid-catalyzed rearrangement of 5,7-di-tert-butyl-2-(4-chloro6,8-dimethylquinolin-2-yl)-1,3-tropolone in concentrated sulfuric acid.

\section{Results and Discussion}

1,3-Tropolone 1 was prepared by the reported method, ${ }^{2}$ and its structure was confirmed by X-ray diffraction. ${ }^{9}$ A distinctive feature of the structure of compound 1 is the presence of a strong intramolecular bond of the $\mathrm{OH}$ group proton of the tropolone ring with the quinoline nitrogen atom. The compound 1 exists in $\mathrm{OH}$ and $\mathrm{NH}$ tautomeric form even in the crystalline state. ${ }^{9}$ Attempts to obtain the salts of compound 1 with sulfuric, hydrochloric and other acids proved unsuccessful. Compound $\mathbf{1}$ is completely soluble in concentrated sulfuric acid to form a tropylium cation, however, this process is reversible even with a slight dilution of the solution with water. An unexpected result was obtained on heating the sulfuric acid solution of 1,3-tropolone 1. It was found that prolonged exposure of 5,7-di-tert-butyl-2-(4-chloro-6,8-dimethylquinolin-2-yl)-1,3-tropolone 1 in concentrated sulfuric acid leads to a previously unknown 5-tert-butyl-2-(4-chloro-6,8-dimethyl-1H-quinolin-2ylidene)-3,3,3a-trimethyl-3,3a-dihydropentalene-1,6(2H,6aH)-dione 3, whose formation can be represented as a cascade process, including the Wagner-Meerwein rearrangement and [1,3]-rearrangement of bicyclo[3.2.1] octane into the pentalene derivative $\mathbf{3}$ (Scheme 1).
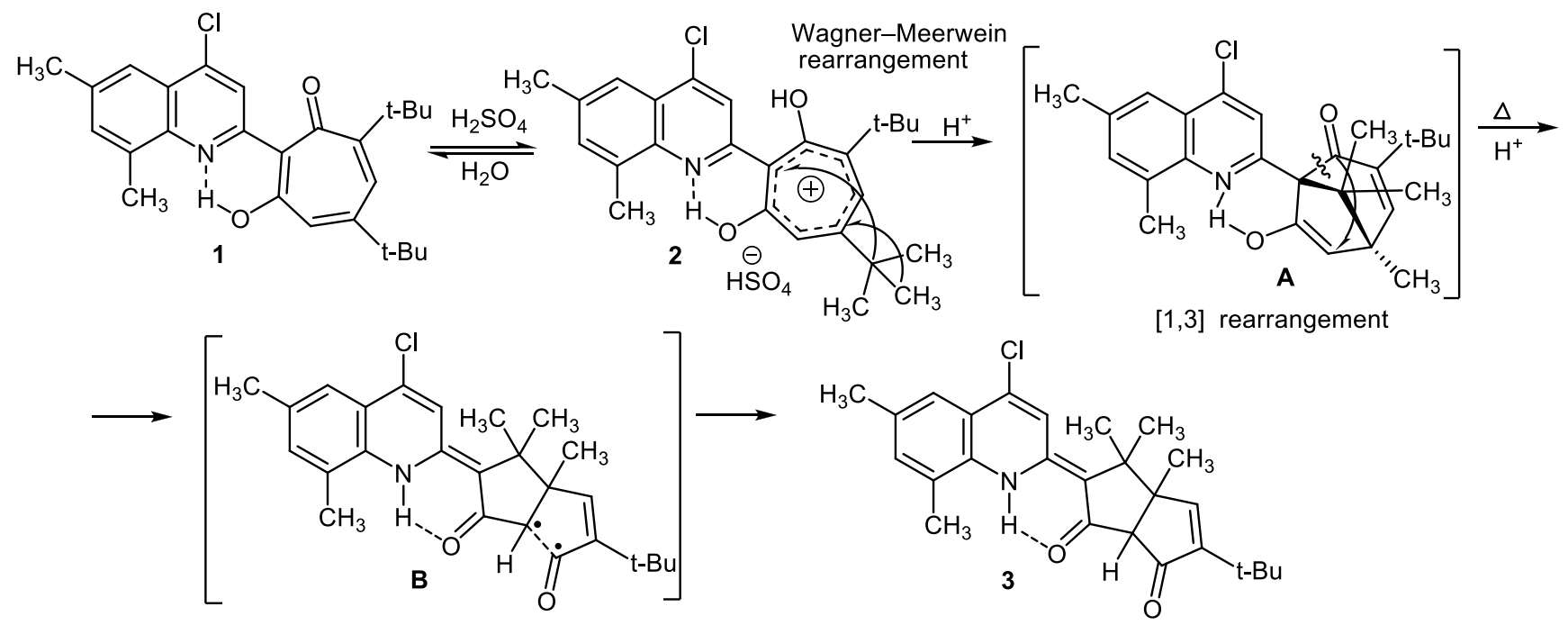

Scheme 1. Synthetic route to 5-tert-butyl-2-(4-chloro-6,8-dimethyl-1H-quinolin-2-ylidene)-3,3,3a-trimethyl3,3a-dihydropentalene-1,6(2H,6aH)-dione (3). 
Acid-catalyzed 1,2-sigmatropic shift of a methyl group from a tert-butyl group in the 5-position of the tropylium cation 2 leads to the formation of a 1-(4-chloro-6,8-dimethylquinolin-2-yl)-7-hydroxy-5,8,8trimethylbicyclo[3.2.1]octa-3,6-dien-2-one derivative $\mathbf{A}$. It is the structure of bicyclo[3.2.1]octan-2-one A, which is advantageous for the subsequent [1,3]-rearrangement leading to formation of the observed product 3 (Scheme 1).

Similar [1,3]-rearrangements, in particular, anionic [1,3]-rearrangements in the series of bicyclo[3.2.1]oct6-en-2-ols, leading to the formation of substituted bicyclo[3.3.0]octanes occur with high yields in the presence of strong bases such as $\mathrm{KN}\left(\mathrm{SiMe}_{3}\right)_{2},{ }^{10} \mathrm{KOBu}^{t},{ }^{11}$ or on photolysis. ${ }^{12}$ Under the conditions of this reaction, the $[1,3]$-rearrangement proceeds under acidic conditions, and is probably initiated by thermal conditions. Given the low yields of compound $\mathbf{3}(10 \%)$ and the isolation of the initial tropolone $\mathbf{1}$ after the completion of the experiment, it can be assumed that the Wagner-Meerwein rearrangement of $\mathbf{1}$ proceeds slowly and is the limiting stage of the cascade process. Optimization of the reaction conditions and a detailed quantumchemical study of the mechanism are the subjects of further research.

The structure of compound $\mathbf{3}$ was established using a combination of methods: mass-spectroscopy, IRspectroscopy, NMR ${ }^{1} \mathrm{H},{ }^{13} \mathrm{C}$, COSY, HSQC, ${ }^{1} \mathrm{H}-{ }^{13} \mathrm{C}$ and ${ }^{1} \mathrm{H}-{ }^{15} \mathrm{~N} \mathrm{HMBC}$, and $\mathrm{X}$-ray analysis. In the course of determination of the structure, the ${ }^{1} \mathrm{H}$ and ${ }^{13} \mathrm{C}$ signals of compound 3 were completely assigned (Figure 1 ). $\mathrm{A}$ comparison with the NMR spectra of the initial tropolone 1 was made as well. ${ }^{13}$
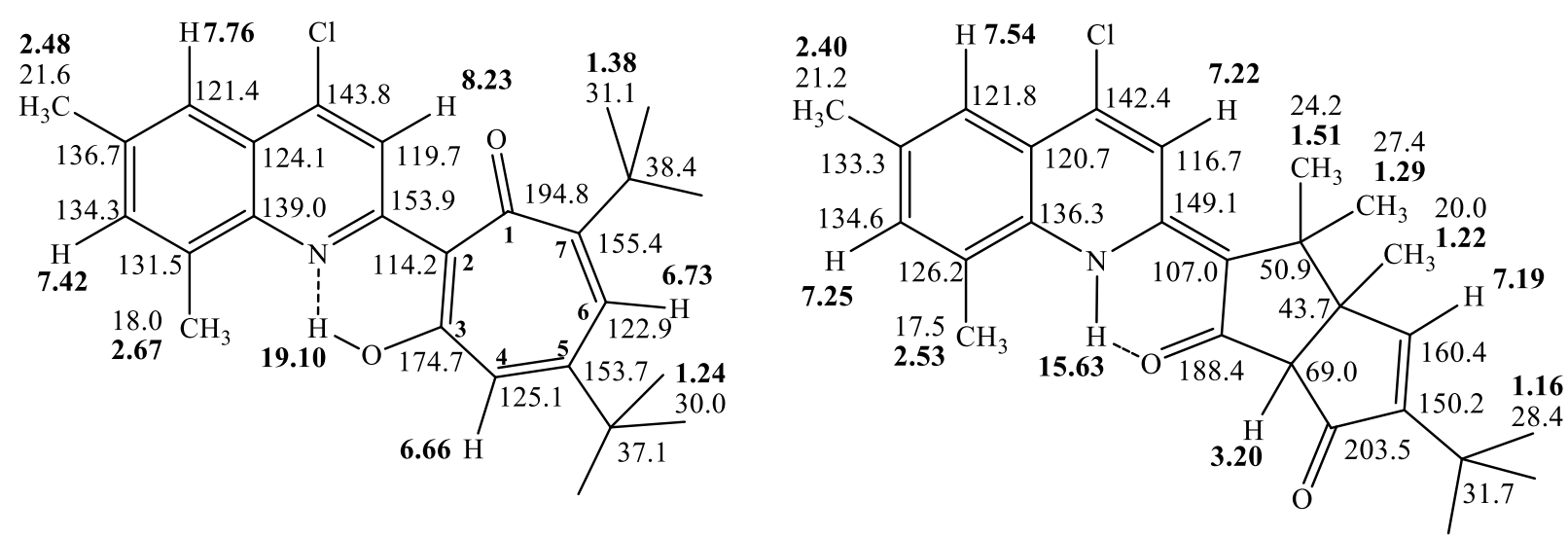

Figure 1. Assignment of ${ }^{1} \mathrm{H}$ and ${ }^{13} \mathrm{C}$ signals in compounds 1 and $\mathbf{3}$.

Equal values of molecular ion peaks and qualitatively identical sets of fragments in the mass spectra of compounds $\mathbf{1}$ and $\mathbf{3}$ indicate their isomeric structures.

Comparison of the NMR spectra allows concluding that there are insignificant differences in the structure of the quinoline fragment in both structures, with the exception of an upfield shift of $1 \mathrm{ppm}$ for $\mathrm{H}\left(3^{\prime}\right)$ peak in compound 3, which is explained by the replacement of the $\mathrm{C}(1)$-carbonyl group of tropolone with a shielding alkyl fragment in the product. In the ${ }^{1} \mathrm{H}$ NMR signals of the transformed tropolonic part of the molecule of compound 3, three three-proton methyl singlets are present instead of the nine-proton singlet of one of the tert-butyl groups. Also one of the protons of the tropone ring changes its position upfield from 6.5-7.0 ppm to $3.20 \mathrm{ppm}$, while the second tropone proton undergoes a downfield shift to $7.19 \mathrm{ppm}$. In the ${ }^{13} \mathrm{C} \mathrm{NMR}$ spectrum of 3 both signals of the $\mathrm{C}=\mathrm{O}$ groups are downfield shifted by approximately 1.0-1.5 ppm. Instead of the disappearing signals at $\delta_{c} 125.1$ and $122.9 \mathrm{ppm}$ and one of the signals of carbons, carrying the tert-butyl group at $\delta_{c} 153.0-155.5 \mathrm{ppm}$, the number of alkyl carbons in the ring increases, which is revealed at $\delta_{c} 50.9$, 43.7, and $69.0 \mathrm{ppm}$. The signal of the carbon connected with $\mathrm{H}$ at $\delta_{\mathrm{H}} 7.19 \mathrm{ppm}$ reveals downfield at $\delta_{\mathrm{c}} 160$ ppm, which is explained by a deshielding conjugation with the carbonyl group. Thus, the number of carbon 
atoms in the resulting ring increased to eight, as the substituents there are two carbonyl oxygens, one tertbutyl and three methyl groups, and since there are two ring protons.

In the ${ }^{1} \mathrm{H}$ NMR spectrum of $\mathbf{3}$ the downfield signal of the hydrogen atom of the hydroxyl group bound by the intramolecular hydrogen bond to the six-membered chelate ring is manifested at $15.63 \mathrm{ppm}$, in contrast to the proton signal of the $\mathrm{OH}$ group in the field of 18.0-19.0 ppm in the ${ }^{1} \mathrm{H}$ NMR spectrum of 2-(4-chloro-6,8dimethylquinolin-2-yl)-5,7-di(tert-butyl)-1,3-tropolone 1 . The hydroxyl carrying carbon resonates at $\delta_{c} 188.4$ $\mathrm{ppm}$, in contrast to the value of $\delta_{\mathrm{c}} 175.0 \mathrm{ppm}$ in the case of tropolone, which indicates its carbonyl nature and the displacement of the proton to the nitrogen atom of the quinoline ring, i.e. the predominance of the $\mathrm{N}-\mathrm{H}$ tautomeric form. This is confirmed by the ${ }^{1} \mathrm{H}-{ }^{13} \mathrm{C}$ HMBC spectrum of isomer 3 , in which cross-peaks of the proton signal of the $\mathrm{N}-\mathrm{H}^{\cdots} \cdot \mathrm{O}$-group at $\delta_{\mathrm{H}} 15.63 \mathrm{ppm}$ with atoms $\mathrm{C}\left(4^{\prime} \mathrm{a}\right)$ and $\mathrm{C}\left(3^{\prime}\right)$ of the quinoline ring and connecting carbon $\mathrm{C}(2)$ at $\delta_{\mathrm{C}} 107.0 \mathrm{ppm}$ of the formed pentalene substituent in the second position of the quinoline are present. In the ${ }^{1} \mathrm{H}_{-}{ }^{15} \mathrm{~N}$ HMBC spectrum of the isomer 3 cross-peaks of the ${ }^{15} \mathrm{~N}$ signal with protons of the $\mathrm{N}-\mathrm{H} \cdots \mathrm{O}$-group and $\mathrm{H}\left(3^{\prime}\right)$ of the quinoline ring are present. The cross-peaks coordinates of the ${ }^{1} \mathrm{H}-{ }^{13} \mathrm{C}$ $\mathrm{HMQC}$ and $\mathrm{HMBC}$ heteronuclear correlations are given in Table 1.

Table 1. Coordinates of cross-peaks in ${ }^{1} \mathrm{H}_{-}{ }^{13} \mathrm{C} \mathrm{HSQC}$ and $\mathrm{HMBC}$ correlation spectra of compound 3

\begin{tabular}{ccc}
\hline \multirow{2}{*}{$\mathbf{H}, \boldsymbol{\delta}, \mathbf{p p m}$} & \multicolumn{2}{c}{${ }^{13} \mathbf{C}, \boldsymbol{\delta}, \mathbf{p p m}$} \\
\cline { 2 - 3 } $15.63(\mathrm{~N}-\mathrm{H} \cdots \mathrm{O})$ & - & $\mathrm{HMBC}$ \\
$7.54\left(\mathrm{H}^{\prime}\right)$ & 121.8 & $120.7,116.7,107.0$ \\
$7.25\left(\mathrm{H}^{\prime}\right)$ & 134.6 & $142.4,136.3,134.6,21.2$ \\
$7.22\left(\mathrm{H}^{\prime}\right)$ & 116.7 & $136.3,121.8,21.2,17.5$ \\
$7.19(\mathrm{H} 4)$ & 160.4 & $149.1,142.4,120.7,107.0$ \\
$3.20\left(\mathrm{H}^{\prime} \mathrm{a}\right)$ & 69.0 & $203.5,150.2,69.0,50.9,31.7,20.0$ \\
$2.53\left(8^{\prime} \mathrm{CH}_{3}\right)$ & 17.5 & $136.3,134.6,126.4$ \\
$2.40\left(6^{\prime} \mathrm{CH}_{3}\right)$ & 21.2 & $188.4,160.4,150.2,107.0,20.0$ \\
$1.51\left(3 \mathrm{CH}_{3}\right)$ & 24.2 & $107.0,50.9,43.7,27.4$ \\
$1.29\left(3 \mathrm{CH}_{3}\right)$ & 27.4 & $107.0,50.9,43.7,24.2$ \\
$1.22(3 \mathrm{aCH}$ & $160.4,69.0,50.9,43.7$ \\
$1.16\left(t-\mathrm{Bu}_{3}\right)$ & 20.0 & $150.2,31.7,28.4$ \\
\hline
\end{tabular}

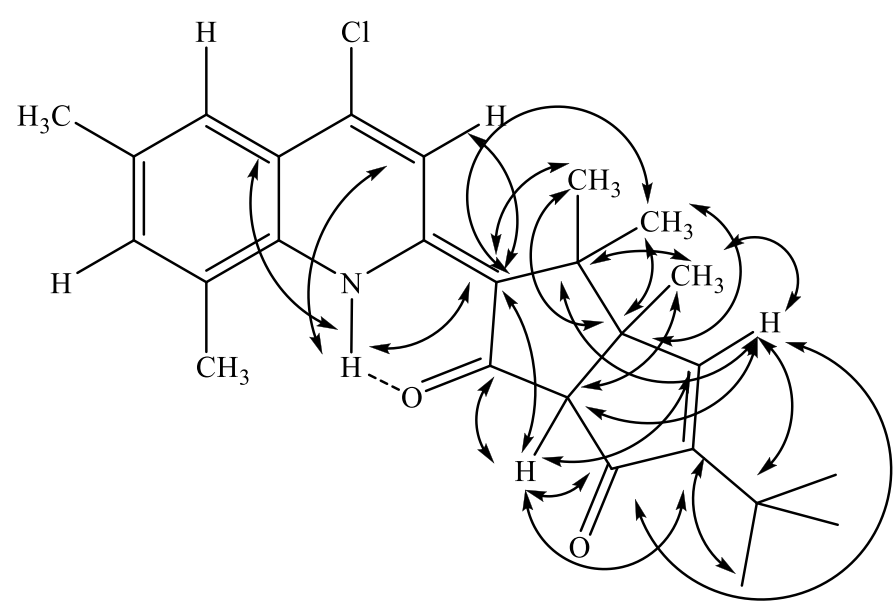

Figure 2. The scheme of the main ${ }^{1} \mathrm{H}_{-}{ }^{13} \mathrm{C} \mathrm{HMBC}$ correlations of compound 3. 
The detailed analysis of these data was a key step in attributing the structure of 2-ylidene substituted 5tert-butyl-3,3,3a-trimethyl-3,3a-dihydropentalene-1,6(2H,6aH)-dione to the product 3 (Figure 1). The most important $\mathrm{HMBC}$ correlations for the analysis of our structure are schematically shown in Figure 2.

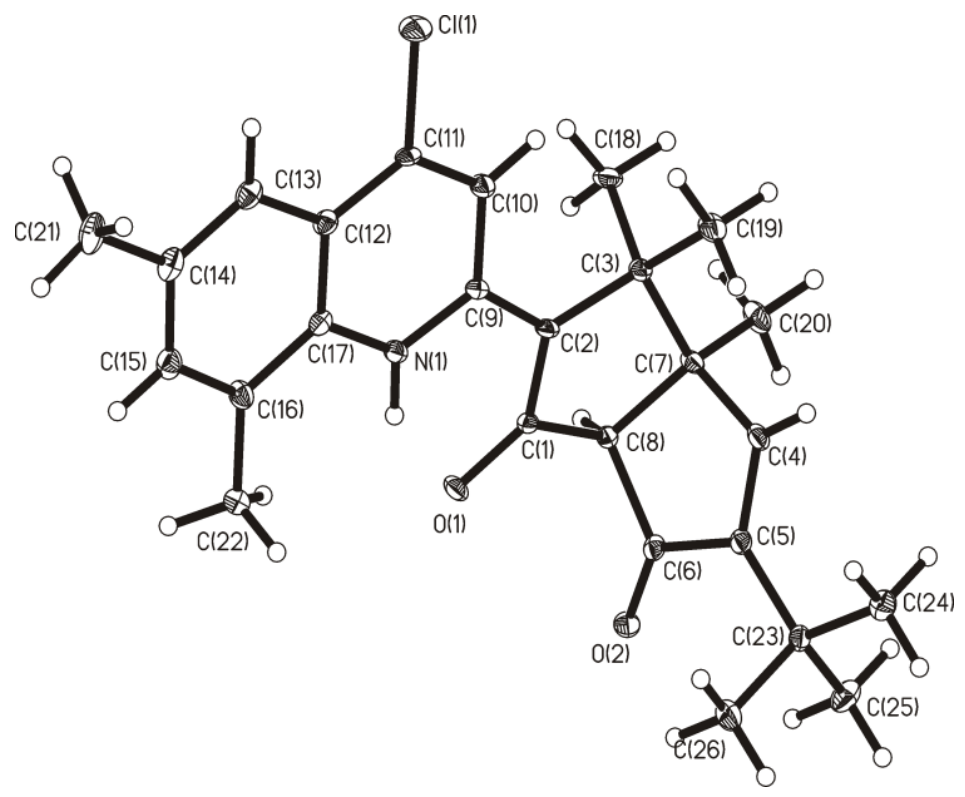

Figure 3. Molecular structure of $(R, S)$-5-tert-butyl-2-(4-chloro-6,8-dimethyl- $1 \mathrm{H}$-quinolin-2-ylidene)-3,3,3atrimethyl-3,3a-dihydropentalene-1,6(2H,6aH)-dione 3.

It may be noted that the quinoline part of the molecule has the structure common to all previously studied (cf. ref. 14 and references therein). The $C(2)-C(9)$ distance in the molecule is $1.412(7) \AA$, that is smaller than $1.462 \AA$ observed in the analogous fragment, ${ }^{15}$ which together with the distances $\mathrm{O}(1)-\mathrm{C}(1)=$ $1.264, C(1)-C(2)=1.409, C(9)-C(10)=1.432$ and $C(10)-C(11)=1.371 \AA$ evidences of conjugation of $\pi-$ orbitals in the atomic chain $O(1)-C(1)-C(2)-C(9)-C(10)-C(11)$ and is supported by the planar structure of the fragment of atoms $C(1)-C(2)-C(3)-C(8)$ lying in the same plane with the quinoline part of the molecule. Intramolecular hydrogen bond is realized in the molecule with parameters $\mathrm{N}(1) \cdots \mathrm{H}(1)=0.88(7), \mathrm{N}(1) \cdots \mathrm{O}(1)=$ $2.621(5), \mathrm{H}(1) \cdots \mathrm{O}(2)=1.90 \AA$, and the angle $\mathrm{N}(1)-\mathrm{H}(1)-\mathrm{O}(1)=138(3)^{\circ}$, which is in good agreement with the parameters of the previously studied 4,5,6,7-tetrachloro-2-(5-chlorobenzothiazolin-2-yl)-1,3-tropolone with analogous parameters $0.94(4), 2.591(3), \mathrm{H}(1) \ldots \mathrm{O}(2)=1.85 \AA$, and the angle $\mathrm{N}(1)-\mathrm{H}(1)-\mathrm{O}(2)=130(3)^{\circ} .16$

The five-membered ring $C(1) C(2) C(3) C(7) C(8)$ has a fold along the line passing through the atoms $C(3)$ and $C(8)$ equal to $151^{\circ}$. The second five-membered ring $C(4) C(5) C(6) C(7) C(8)$ is not flat either and the deviation of atoms $C(4)$ and $C(6)$ from the plane $C(5) C(7) C(8)$ are 0.25 and $0.35 \AA$ in opposite directions, respectively. The inflection along the line $C(7)-C(8)$ between the planes $C(5) C(7) C(8)$ and $C(5) C(7) C(8)$ is $130^{\circ}$. The values of important bond lengths and valence angles are given in Table 2.

To assess the relative thermodynamic stability of $(\mathrm{NH})$ and $(\mathrm{OH})$ isomers $3, \mathrm{PBE} / 6-311+\mathrm{G}(\mathrm{d}, \mathrm{p})$ calculations of energetic and structural characteristics of the respective structures in the gas phase and DMSO solution were performed, the results of which are shown in Figure 4 and Tables 2,3 

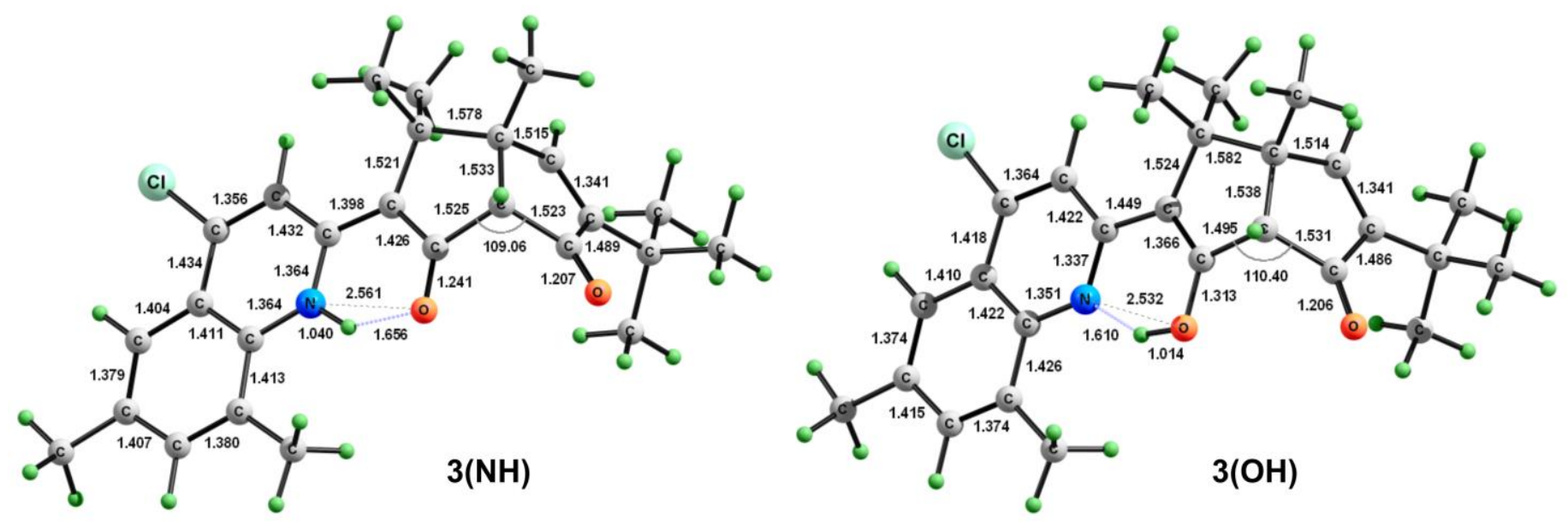

Figure 4. Structural characteristics of $(\mathrm{NH})$ and $(\mathrm{OH})$ tautomeric forms of $\mathbf{3}$ according to the PBE0/6$311+G(d, p)$ calculations in the gas phase. The bond lengths are given in Ångstroms.

Table 2. Calculated ( $\left.d_{\text {calc }}, \omega_{\text {calc }}\right)$ and experimentally observed ( $\left.d_{\text {exp }}, \omega_{\exp }\right)$ structural parameters of $\mathbf{3}(\mathrm{NH})$

\begin{tabular}{cccccc}
\hline Bond & $\mathrm{d}_{\text {calc }} / \AA$ & $\mathrm{d}_{\text {exp }} / \AA$ & Angle & $\omega_{\text {calc }} /$ deg & $\omega_{\text {exp }} /$ deg \\
\hline $\mathrm{C}(1)-\mathrm{C}(2)$ & 1.426 & $1.409(7)$ & $\mathrm{C}(9)-\mathrm{N}(1)-\mathrm{C}(17)$ & 125.4 & $124.4(4)$ \\
$\mathrm{C}(2)-\mathrm{C}(3)$ & 1.521 & $1.531(7)$ & $\mathrm{O}(1)-\mathrm{C}(1)-\mathrm{C}(2)$ & 127.6 & $128.1(5)$ \\
$\mathrm{C}(3)-\mathrm{C}(7)$ & 1.578 & $1.585(7)$ & $\mathrm{O}(1)-\mathrm{C}(1)-\mathrm{C}(8)$ & 122.6 & $122.3(4)$ \\
$\mathrm{C}(7)-\mathrm{C}(4)$ & 1.515 & $1.520(8)$ & $\mathrm{C}(2)-\mathrm{C}(1)-\mathrm{C}(8)$ & 109.9 & $109.6(4)$ \\
$\mathrm{C}(4)-\mathrm{C}(5)$ & 1.341 & $1.355(7)$ & $\mathrm{C}(1)-\mathrm{C}(2)-\mathrm{C}(9)$ & 119.7 & $120.7(5)$ \\
$\mathrm{C}(5)-\mathrm{C}(6)$ & 1.489 & $1.492(7)$ & $\mathrm{C}(1)-\mathrm{C}(2)-\mathrm{C}(3)$ & 111.1 & $112.1(4)$ \\
$\mathrm{C}(6)-\mathrm{C}(8)$ & 1.523 & $1.519(7)$ & $\mathrm{C}(9)-\mathrm{C}(2)-\mathrm{C}(3)$ & 128.7 & $126.6(4)$ \\
$\mathrm{C}(2)-\mathrm{C}(9)$ & 1.398 & $1.412(7)$ & $\mathrm{C}(2)-\mathrm{C}(3)-\mathrm{C}(7)$ & 101.8 & $100.8(4)$ \\
$\mathrm{N}(1)-\mathrm{C}(9)$ & 1.364 & $1.368(7)$ & $\mathrm{C}(5)-\mathrm{C}(4)-\mathrm{C}(7)$ & 114.9 & $113.6(5)$ \\
$\mathrm{C}(1)-\mathrm{O}(1)$ & 1.241 & $1.264(6)$ & $\mathrm{C}(4)-\mathrm{C}(5)-\mathrm{C}(6)$ & 107.8 & $107.4(5)$ \\
$\mathrm{C}(6)-\mathrm{O}(2)$ & 1.207 & $1.216(6)$ & $\mathrm{O}(2)-\mathrm{C}(6)-\mathrm{C}(5)$ & 127.6 & $127.5(5)$ \\
$\mathrm{C}(9)-\mathrm{C}(10)$ & 1.432 & $1.432(7)$ & $\mathrm{O}(2)-\mathrm{C}(6)-\mathrm{C}(8)$ & 125.7 & $125.2(5)$ \\
$\mathrm{C}(10)-\mathrm{C}(11)$ & 1.356 & $1.371(7)$ & $\mathrm{C}(5)-\mathrm{C}(6)-\mathrm{C}(8)$ & 106.8 & $107.2(4)$ \\
$\mathrm{C}(11)-\mathrm{C}(12)$ & 1.434 & $1.420(8)$ & $\mathrm{C}(4)-\mathrm{C}(7)-\mathrm{C}(8)$ & 101.3 & $101.5(4)$ \\
$\mathrm{C}(12)-\mathrm{C}(17)$ & 1.411 & $1.408(7)$ & $\mathrm{C}(4)-\mathrm{C}(7)-\mathrm{C}(3)$ & 113.0 & $114.5(4)$ \\
$\mathrm{N}(1)-\mathrm{C}(17)$ & 1.364 & $1.385(7)$ & $\mathrm{C}(6)-\mathrm{C}(8)-\mathrm{C}(1)$ & 109.1 & $110.9(4)$ \\
\hline
\end{tabular}


Table 3. Total energies with zero-point energy correction ( $E_{\text {tot }}+Z P E$, a.u.) and relative energies $(\Delta E, \mathrm{kcal} / \mathrm{mol})$ of isomers of compound 3 calculated using the $\mathrm{PBEO} / 6-311+\mathrm{G}(\mathrm{d}, \mathrm{p})$ method in the gas phase and in DMSO solution

\begin{tabular}{ccccc}
\hline Compound & $\mathrm{E}_{\text {tot }}+\mathrm{ZPE}(\mathrm{gas})$ & $\Delta \mathrm{E}_{\text {gas }}$ & $\mathrm{E}_{\text {tot }}+\mathrm{ZPE}(\mathrm{sol})$ & $\Delta \mathrm{E}_{\text {sol }}$ \\
\hline $\mathbf{3}(\mathrm{NH})$ & -1672.510118 & 0 & -1672.5255 & 0 \\
$\mathbf{3}(\mathrm{OH})$ & -1672.507957 & 1.4 & -1672.52099 & 2.8 \\
\hline
\end{tabular}

The obtained results revealed the essential stabilization of the $(\mathrm{NH})$ form of $\mathbf{3}$ with respect to the $(\mathrm{OH})$ isomer, which becomes energy-preferable in polar medium. In contrast, for the parent compound $1, \mathrm{the}(\mathrm{OH})$ form is more stable. ${ }^{17}$ Previous studies of tropolone derivatives have shown that the stabilization of the (NH) isomer is directly related to the enhancement of the electron-withdrawing properties of the tropolone fragment (for example, by introducing appropriate substituents). Therefore, it can be assumed that the isomerization product of the tropolone ring - the dihydropentalene fragment of $\mathbf{3}$ - possesses a more pronounced electron-withdrawing properties than the initial tropolone moiety.

\section{Conclusions}

We have prepared 5-tert-butyl-2-(4-chloro-6,8-dimethyl-1H-quinolin-2-ylidene)-3,3,3a-trimethyl-3,3a-dihydropentalene-1,6(2H,6aH)-dione, the structure of which was established by the heteronuclear 2D NMR spectroscopy methods and X-ray analysis. The compound has predominantly the NH tautomeric form. This conclusion is supported by the data of NMR spectroscopy and X-ray analysis, as well as by theoretical modeling. Stabilization of the $\mathrm{NH}$ isomer is significantly enhanced in a polar solvent. The mechanism of the acid-catalyzed cascade isomerization reaction of 5,7-di(tert-butyl)-2-(4-chloro-6,8-dimethylquinolin-2-yl)-1,3tropolone may include a Wagner-Meerwein rearrangement and the [1,3]-rearrangement of a bicyclo[3.2.1]octane intermediate into the pentalene derivative.

\section{Experimental Section}

General. The ${ }^{1} \mathrm{H},{ }^{13} \mathrm{C}$, and ${ }^{15} \mathrm{~N}$ NMR spectra were recorded on a Bruker Avance 600 spectrometer. The chemical shifts are given with respect to the signal of $\mathrm{SiMe}_{4}$ as the internal standard. Attenuated total internal reflectance IR (ATR-IR) spectra were measured on a Varian 3100 FT-IR Excalibur Series spectrometer. The electron ionization mass spectra were obtained on a Shimadzu GCMS-QP2010SE spectrometer with direct injection of the sample into the ion source $(70 \mathrm{eV})$. Chromatography was performed on columns packed with $\mathrm{Al}_{2} \mathrm{O}_{3}$ (Brockmann activity II-III). The melting point was measured on a Fisher-Johns apparatus. The IR and NMR spectra were recorded using equipment of the Shared Use Center "Molecular spectroscopy" of the Southern Federal University.

5,7-Di-tert-butyl-2-(4-chloro-6,8-dimethylquinolin-2-yl)-1,3-tropolone (1) was obtained by the method of Minkin et al. ${ }^{2}$ the physicochemical data were reported earlier. ${ }^{13}$

$(R, S)$-5-tert-Butyl-2-(4-chloro-6,8-dimethyl-1H-quinolin-2-ylidene)-3,3,3a-trimethyl-3,3a-dihydropenta-lene-

1,6(2H,6aH)-dione (3). 5,7-Di-tert-butyl-2-(4-chloro-6,8-dimethylquinolin-2-yl)-1,3-tropolone (1) (1.27 g, 3.2 
mmol) dissolved in concentrated sulfuric acid $(20 \mathrm{ml})$ was heated for 7 days at $110{ }^{\circ} \mathrm{C}$. The mixture was poured onto $100 \mathrm{~g}$ of ice and neutralized with a solution of $\mathrm{NaOH}(40 \%)$ to $\mathrm{pH}$ 7. The solution was extracted with methylene chloride $(3 \times 100 \mathrm{ml})$. The nonaqueous solution was washed with water $(2 \times 100 \mathrm{ml})$ and dried with anhydrous $\mathrm{Na}_{2} \mathrm{SO}_{4}$, and the bulk of the methylene chloride was distilled off. The residue was passed through a chromatographic column with $\mathrm{Al}_{2} \mathrm{O}_{3}$ (eluant petroleum ether 40-70': methylene chloride 1: 1). $\mathrm{A}$ yellow-orange fraction with $\mathrm{R}_{f} 0.2$ was collected. $0.14 \mathrm{~g}$ of compound 3 was obtained. Yellow crystals, yield 10\%, mp 200-201 ${ }^{\circ} \mathrm{C}$ (propan-2-ol). IR: $v_{\max } 3118,1709,1620,1606,1592,1570,1526,1470,1446,1431,1396$, $1371,1362,1345,1319,1298,1280,1267,1236,1215,1166,1157,1140,1109,1089,1069,1048,1039,1006$, 970, 952, 897, 883, 856, 823, $752 \mathrm{~cm}^{-1} .{ }^{1} \mathrm{H}$ NMR (CDCl$): 1.16$ (c, 9H, Bu$\left.{ }^{t}\right), 1.22$ (c, 3H, Me(3a)), 1.29 (c, 3H,

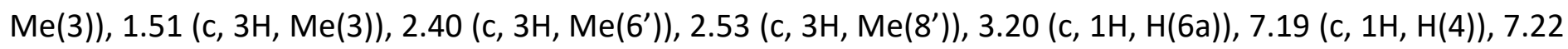
(c, $\left.1 \mathrm{H}, \mathrm{H}\left(3^{\prime}\right)\right), 7.25$ (c, $\left.1 \mathrm{H}, \mathrm{H}\left(7^{\prime}\right)\right), 7.54$ (c, 1H, H(5')), 15.63 (c, 1H, NH(1)). ${ }^{13} \mathrm{C} \mathrm{NMR}\left(\mathrm{CDCl}_{3}\right): 17.5\left(\mathrm{Me}\left(8^{\prime}\right)\right), 20.0$ (Me(3a)), $21.2\left(\mathrm{Me}\left(6^{\prime}\right)\right), 24.2(\mathrm{Me}(3)), 27.4(\mathrm{Me}(3)), 28.4\left(3 \mathrm{C}, \mathrm{C}\left(\underline{\mathrm{C}} \mathrm{H}_{3}\right)_{3}\right), 31.7\left(\underline{\mathrm{C}}\left(\mathrm{CH}_{3}\right)_{3}\right), 43.7(\mathrm{C}(3 \mathrm{a})), 50.9(\mathrm{C}(3))$, $69.0(\mathrm{C}(6 \mathrm{a})), 107.0(\mathrm{C}(2)), 116.7\left(\mathrm{C}\left(3^{\prime}\right)\right), 120.7\left(\mathrm{C}\left(4^{\prime} \mathrm{a}\right)\right), 121.8\left(\mathrm{C}\left(5^{\prime}\right)\right), 126.2\left(\mathrm{C}\left(8^{\prime}\right)\right), 133.3\left(\mathrm{C}\left(6^{\prime}\right)\right), 134.6\left(C\left(7^{\prime}\right)\right)$, $136.3\left(C\left(8 a^{\prime}\right)\right), 142.4\left(C\left(4^{\prime}\right)\right), 149.1\left(C\left(2^{\prime}\right)\right), 150.2(C(5)), 160.4(C(4)), 188.4(C(1)), 203.5(C(6)) . M S: m / z(\%): 423$ (70) [M+], 408 (95), 380 (13), 272 (72), 260 (20), 245 (100), 230 (24), 210 (65), 205 (23), 191 (30), 135 (20), 122 (43), 107 (45), 91 (30), 77 (18), 57 (52). Calc. for $\mathrm{C}_{26} \mathrm{H}_{30} \mathrm{CINO}_{2}$ : C, 73.66; H, 7.08; N, 3.30. Found: C, 73.42; H, $6.84 ; \mathrm{N}, 3.10 \%$.

\section{X-ray crystal data}

Single crystals of the compound were obtained by crystallization from isopropanol. The parameters of the unit cell of the crystal and the three-dimensional intensity set were obtained at a temperature of $150 \mathrm{~K}$ on an autodiffractometer 'Xcalibur, Eos' (MoKa radiation, graphite monochromator). Monocrystals of $\mathrm{C}_{26} \mathrm{H}_{30} \mathrm{CINO}_{2}, \mathrm{M}=$ 423.96 are monoclinic: $a=7.2496(3), b=15.0064(6), c=20.7670$ (7) $\AA, b=97.80(36)^{\circ} . V=2238.3(1), Z=4, r$ $($ subtraction $)=1.258 \mathrm{~g} / \mathrm{cm}^{3}, \mathrm{~m}$ (MoKa) $=0.19 \mathrm{~mm}-1$, pr.gr. P21 / c. The intensities of the 19967 reflections were measured in the angular interval $(2 \theta \leq 68.14)$ by the $w$-scan method from a single crystal measuring 0.24 $\times 0.07 \times 0.06 \mathrm{~mm}$, of which 9197 are independent. The structure is deciphered by a direct method and refined by the full-matrix least squares (OLS) method in accordance with the SHELXTL program in the anisotropic approximation for non-hydrogen atoms. Coordinates of atoms and accompanying structural information can be obtained at vatka@icp.ac.ru .

\section{Computational methods}

All quantum chemical calculations were performed at PBE0/6-311+G(d,p) level of theory using the Gaussian 09 suite of programs. ${ }^{18}$ Solvent effects were modeled by using polarizable continuum model (PCM) ${ }^{19}$ within the integral equation formalism (IEFPCM). ${ }^{20}$

\section{Acknowledgements}

This study was supported by the Russian Foundation for Basic Research (Project No. 17-53-540003_Viet_a), International grant VAST.HTQT.NGA.08/17-18 and the Vietnam National Foundation for Science and Technology Development "NAFOSTED" (grant 104.01-2015.68). 


\section{References}

1. Zhao, J. Current Med. Chem. 2007, 14, 2597.

https://doi.org/10.2174/092986707782023253

2. Minkin, V. I.; Aldoshin, S. M.; Komissarov, V. N.; Dorogan, I. V.; Sayapin, Yu. A.; Tkachev, V. V.; Starikov, A. G.; Russ. Chem. Bull. 2006, 55, 1956.

https://doi.org/10.1007/s11172-006-0547-x

3. Sayapin, Yu. A.; Duong, B. N.; Komissarov, V. N.;.Dorogan, I. V.; Makarova, N. I.; Bondareva, I. O.; Tkachev, V. V.; Shilov, G. V.; Aldoshin, S. M.; Minkin. V. I. Tetrahedron 2010, 66, 8763.

https://doi.org/10.1016/i.tet.2010.08.077

4. Sayapin, Yu. A.; Komissarov, V. N.; Duong, B. N.; Dorogan, I. V.; Minkin, V. I.; Tkachev, V. V.; Shilov, G. V.; Aldoshin, S. M.; Charushin V. N. Mendeleev Commun. 2008, 18, 180.

https://doi.org/10.1016/j.mencom.2008.07.002

5. Sayapin, Yu. A.; Tupaeva, I. O.; Kolodina, A. A.; Komissarov, V. N.; Dorogan, I. V.; Makarova, N. I.; Metelitsa, A. V.; Tkachev, V. V.; Aldoshin, S. M.; Minkin, V. I. Beilstein J. Org. Chem. 2015, 11, 2179. https://doi.org/10.3762/bjoc.11.236

6. Sayapin, Yu. A.; Gusakov, E. A.; Dorogan, I. V.; Tupaeva, I. O.; Teimurazov, M. G.; Fursova, N. K.; Ovchinnikov, K. V.; Minkin, V. I. Russ. J. Bioorg. Chem. 2016, 42, 224.

https://doi.org/10.1134/S1068162016020114

7. Sayapin, Yu. A.; Gusakov, E.A.; Kolodina, A. A.; Komissarov, V. N.; Dorogan, I. V.; Tkachev, V. V.; Shilov, G. V.; Nosova, E. V.; Aldoshin, S. M.; Charushin, V. N.; Minkin V. I. Russ. Chem. Bull. 2014, 63, 1364. https://doi.org/10.1007/s11172-014-0604-9

8. Duong, N. B., Sayapin, Yu. A., Khoang, L., Nguen, D. D., Komissarov, V. N. Chemistry of Heterocyclic Compounds. 2015, 51, 291. https://doi.org/10.1007/s10593-015-1697-2

9. Tkachev, V. V.; Sayapin, Yu. A.; Shilov, G. V.; Komissarov, V. N.; Aldoshin, S. M.; Minkin V. I. J. Struct. Chem. 2016, 57, 622. https://doi.org/10.1134/S0022476616030239

10. Hashimoto, H.; Abe, Y.; Mayuzumi, Y.; Karikomi, M.; Seki, K.; Haga, K.; Uyehara, T. Tetrahedron Lett. 2002, 43, 265.

https://doi.org/10.1016/S0040-4039(01)02036-6

11. Presset, M.; Coquerel, Y.; Rodriguez, J. Chem. Rev. 2013, 113, 525.

https://doi.org/10.1021/cr200364p

12. Nair, V.; Maliakal, D.; Anilkumar, G.; Rath, N. P. Synlett 2000, 8, 1139.

http://doi.org/10.1055/s-2000-6741

13. Borodkin, G. S.; Kolodina, A. A.; Dorogan, I. V.; Gusakov, E. A.; Borodkina, I. G.; Chepurnoi, P. B.; Sayapin Yu. A. Dokl. Chem. 2017, 472, 11. https://doi.org/10.1134/S0012500817010049

14. Sayapin, Yu. A.; Gusakov, E. A.; Bang, Z. N.; Tupaeva, I. O.; Komissarov, V. N.; Dorogan, I. V.; Tkachev, V. V.; Aldoshin, S. M.; Minkin, V. I. Russ. Chem. Bull. 2013, 62, 480.

https://doi.org/10.1007/s11172-013-0067-4

15. Tkachev, V. V.; Sayapin, Yu. A.; Shilov, G. V.; Utenyshev, A. N.; Bozhenko, K. V.; Komissarov, V. N.; Aldoshin, S. M.; Minkin V. I. J. Struct. Chem. 2015, 56, 1154. 
16. Bondareva, I. O.; Sayapin, Yu. A.; Komissarov, V. N.; Tkachev, V. V.; Shilov, G. V.; Aldoshin, S. M.; Minkin, V. I. Russ. Chem. Bull. 2011, 60, 1384.

https://doi.org/10.1007/s11172-011-0207-7

17. Borodkin, G. S.; Kolodina, A. A.; Dorogan, I. V.; Gusakov, E. A.; Borodkina, I. G.; Chepurnoi, P. B.; Sayapin, Yu. A. Dokl. Chem. 2017, 472, 11.

https://doi.org/10.1134/S0012500817010049

18. Frisch, M. J.; Trucks, G. W.; Schlegel, H. B.; Scuseria, G. E.; Robb, M. A.; Cheeseman, J. R.; Scalmani, G.; Barone, V.; Mennucci, B.; Petersson, G. A.; Nakatsuji, H.; Caricato, M.; Li, X.; Hratchian, H. P.; Izmaylov, A. F.; Bloino, J.; Zheng, G.; Sonnenberg, J. L.; Hada, M.; Ehara, M.; Toyota, K.; Fukuda, R.; Hasegawa, J.; Ishida, M.; Nakajima, T.; Honda, Y.; Kitao, O.; Nakai, H.; Vreven, T.; Montgomery, J.; Peralta, J. E.; Ogliaro, F.; Bearpark, M.; Heyd, J. J.; Brothers, E.; Kudin, K. N.; Staroverov, V. N.; Kobayashi, R.; Normand, J.; Raghavachari, K.; Rendell, A.; Burant, J. C.; Iyengar, S. S.; Tomasi, J.; Cossi, M.; Rega, N.; Millam, N. J.; Klene, M.; Knox, J. E.; Cross, J. B.; Bakken, V.; Adamo, C.; Jaramillo, J.; Gomperts, R.; Stratmann, R. E.; Yazyev, O.; Austin, A. J.; Cammi, R.; Pomelli, C.; Ochterski, J. W.; Martin, R. L.; Morokuma, K.; Zakrzewski, V. G.; Voth, G. A.; Salvador, P.; Dannenberg, J. J.; Dapprich, S.; Daniels, A. D.; Farkas, Ö.; Foresman, J. B.; Ortiz, J. V.; Cioslowski, J.; Fox D. J. Gaussian 09, Revision A.01; Gaussian, Inc.: Wallingford, CT, 2009.

19. Barone, V.; Cossi, M.; Tomasi, J. J. Chem. Phys. 1997, 107, 3210.

https://doi.org/10.1063/1.474671

20. Cances, E.; Mennucci, B.; Tomasi, J. J. Chem. Phys. 1997, 107, 3032.

https://doi.org/10.1063/1.474659 